\title{
MicroRNA-29a is up-regulated in beta-cells by glucose and decreases glucose- stimulated insulin secretion
}

Bagge, Annika; Clausen, Trine Ryberg; Ladefoged, Mette; Rosenstierne, Maiken Worsøe; Louise, Larsen ; Vang, Ole; Nielsen, Jens Høiriis ; Dalgaard, Louise Torp; Larsen, Sylvester Published in:

Biochemical and Biophysical Research Communications

DOI:

10.1016/j.bbrc.2012.08.082

Publication date:

2012

Document Version

Early version, also known as pre-print

Citation for published version (APA):

Bagge, A., Clausen, T. R., Ladefoged, M., Rosenstierne, M. W., Louise, L., Vang, O., Nielsen, J. H., Dalgaard, L. T., \& Larsen, S. (2012). MicroRNA-29a is up-regulated in beta-cells by glucose and decreases glucosestimulated insulin secretion. Biochemical and Biophysical Research Communications, 426(2), 266-272. https://doi.org/10.1016/j.bbrc.2012.08.082

\section{General rights}

Copyright and moral rights for the publications made accessible in the public portal are retained by the authors and/or other copyright owners and it is a condition of accessing publications that users recognise and abide by the legal requirements associated with these rights.

- Users may download and print one copy of any publication from the public portal for the purpose of private study or research.

- You may not further distribute the material or use it for any profit-making activity or commercial gain.

- You may freely distribute the URL identifying the publication in the public portal.

Take down policy

If you believe that this document breaches copyright please contact rucforsk@kb.dk providing details, and we will remove access to the work immediately and investigate your claim. 


\title{
MicroRNA-29a is up-regulated in beta-cells by glucose and decreases glucose-stimulated insulin secretion
}

\author{
4 Q1 Annika Bagge a, Trine R. Clausen ${ }^{\mathrm{b}}$, Sylvester Larsen ${ }^{\mathrm{a}}$, Mette Ladefoged ${ }^{\mathrm{b}}$, Maiken W. Rosenstierne ${ }^{\mathrm{a}, \mathrm{d}}$, \\ 5 Louise Larsen ${ }^{c}$, Ole Vang ${ }^{\mathrm{a}}$, Jens H. Nielsen ${ }^{\mathrm{c}}$, Louise T. Dalgaard ${ }^{\mathrm{a}, *}$ \\ $6 \quad$ a Department of Science, Systems and Models, Roskilde University, Roskilde, Denmark \\ ${ }^{\mathrm{b}}$ Diabetes Biology, Novo Nordisk, Maaloev, Denmark \\ ${ }^{\mathrm{c}}$ Department of Biomedical Sciences, University of Copenhagen, Copenhagen, Denmark \\ ${ }^{\mathrm{d}}$ Department of Virology, Statens Serum Institut, Denmark
}

\section{A R T I C L E I N F O}

\section{Article history:}

Received 15 August 2012

Available online xxxx

\section{Keywords:}

MicroRNA

Beta-cell

Islets of Langerhans

MicroRNA-29a

Glucose toxicity

Beta-cell dysfunction

\begin{abstract}
A B S T R A C T
Chronically elevated levels of glucose impair pancreatic beta-cell function while inducing beta-cell proliferation. MicroRNA-29a (miR-29a) levels are increased in several tissues in diabetic animals and mediate decreased insulin-stimulated glucose-transport of adipocytes. The aim was to investigate the impact of glucose on miR-29a levels in INS-1E beta-cells and in human islets of Langerhans and furthermore to evaluate the impact of miR-29a on beta-cell function and proliferation. Increased glucose levels up-regulated miR-29a in beta-cells and human and rat islets of Langerhans. Glucose-stimulated insulin-secretion (GSIS) of INS-1E beta-cells was decreased by forced expression of miR-29a, while depletion of endogenous miR-29a improved GSIS. Over-expression of miR-29a increased INS-1E proliferation. Thus, miR-29a up-regulation is involved in glucose-induced proliferation of beta-cells. Furthermore, as depletion of miR-29a improves beta-cell function, miR-29a is a mediator of glucose-induced beta-cell dysfunction. Glucose-induced up-regulation of miR-29a in beta-cells could be implicated in progression from impaired glucose tolerance to type 2 diabetes.
\end{abstract}

(C) 2012 Published by Elsevier Inc.

\section{Introduction}

Type 2 diabetes mellitus is a complex metabolic disorder involving two core defects: insulin resistance and beta-cell dysfunction, both of which are present in pre-diabetic states and act in concert to progressively exacerbate glucose intolerance. Elevated plasma glucose levels (post-prandially or chronically) lead to decreased glucose-stimulated insulin secretion (GSIS) and beta-cell dysfunction [1]. The mechanisms underlying glucoseinduced beta-cell dysfunction, or glucose toxicity, are incompletely understood, but involve beta-cell exhaustion from continued insulin release as well as mitochondrial dysfunction [2-4], however, an increased glucose level is also a powerful beta-cell mitogen [5].

MicroRNAs (miRNAs) are regulators of gene expression at the post-transcriptional level and function by partially binding to the

Abbreviations: miRNA, microRNA; LNA, locked nucleic acid; GSIS, glucosestimulated insulin secretion.

* Corresponding author. Address: Department of Science, Roskilde University, Universitetsvej 1, Bldg. 18.1, P.O. Box 260, 4000 Roskilde, Denmark. Fax: +45 4674 3011.

E-mail address: Itd@ruc.dk (L.T. Dalgaard). 3'untranslated region (UTR) of their target gene transcripts either mediating transcript degradation or translational inhibition [68]. Several miRNAs have been implicated in beta-cell function: miR-9, miR-30d, miR-124, miR-133a and miR-375 are involved in glucose-dependent regulation of insulin transcription and/or insulin release in beta-cells by targeting beta-cell transcription factors and/or transcripts involved in insulin exocytosis [9-15]. Furthermore, fatty acid induced increase in miR-34a levels may cause beta-cell dysfunction [16].

miR-29a is up-regulated by glucose in skeletal muscle, liver and white adipose tissue, where it leads to insulin resistance [17-19]. We hypothesized that miR-29a could be similarly regulated by glucose in pancreatic beta-cells and mediate glucose-induced dysfunction. Thus, the aim of this study was to determine the glucosedependent regulation of miR-29a in beta-cells, as well as effects on GSIS.

Our results indicate that glucose-mediated up-regulation of miR-29a in beta-cells mediates beta-cell dysfunction and increased beta-cell proliferation, while inhibition of miR-29a improves GSIS. Thus, the up-regulation of miR-29a by glucose could be a link between glucose-induced proliferation and beta-cell dysfunction. 
A

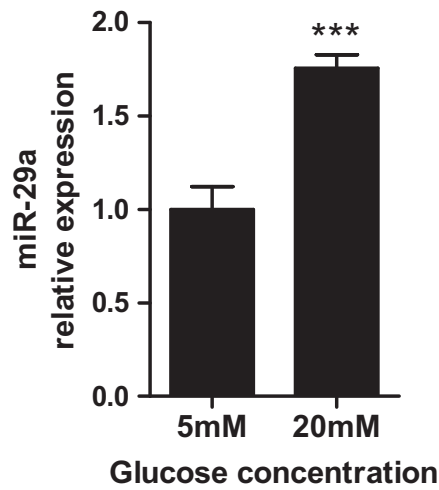

D

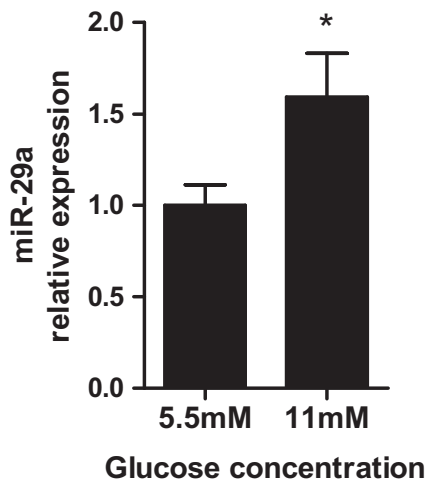

B

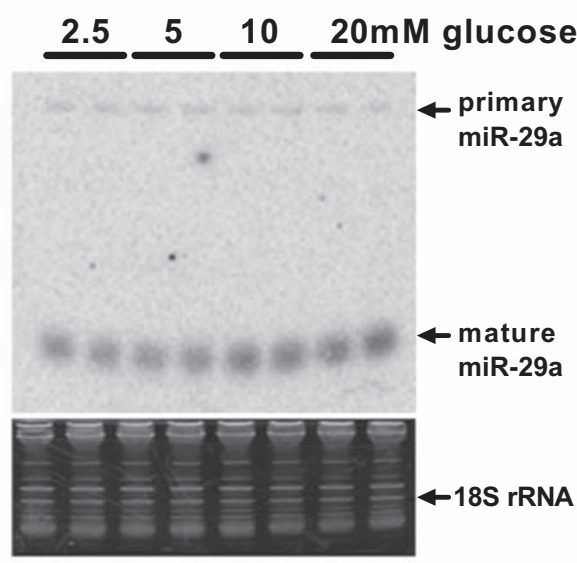

C

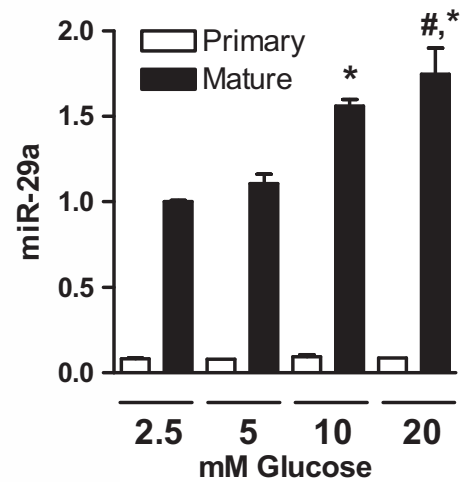

E

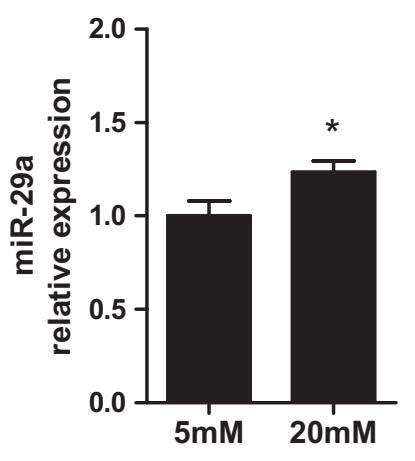

Glucose concentration

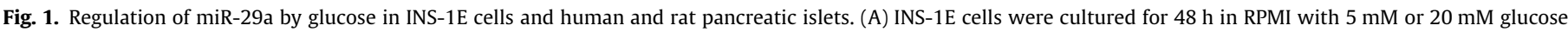

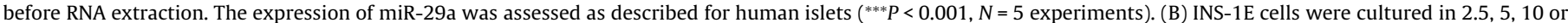

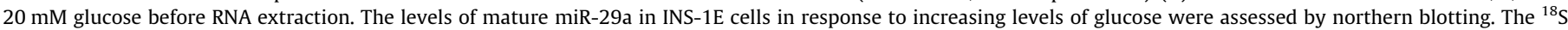

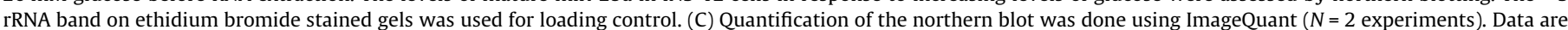

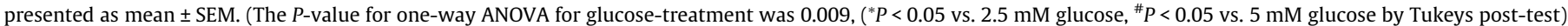

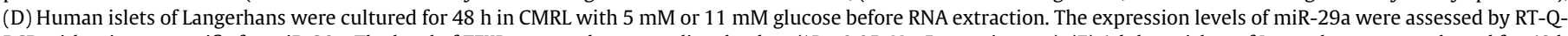

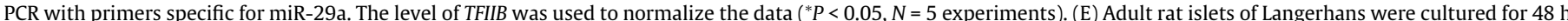

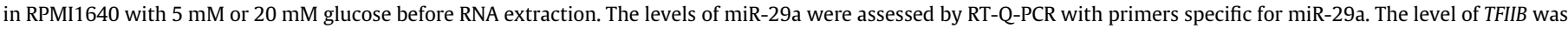
used to normalize the data ( ${ }^{*} P<0.05, N=3$ experiments).

\section{Materials and methods}

\subsection{Cell culture and nucleofection}

INS-1E cells (gift from Claes Wollheim, Geneva, Switzerland) were cultured in RPMI as described previously [20]. Cells $\left(4 \times 10^{6}\right)$ were nucleofected using a Nucleofector (Amaxa, Lonza, Copenhagen, Denmark) with miR-29a LNA knock-down or scrambled LNA oligonucleotide (Exiqon, Vedbaek, Denmark), or with miRIDIAN miR-29a mimic or the miRIDIAN negative control \#2 (Dharmacon, ThermoFisher Scientific, Slangerup, Denmark). Nucleofected cells were seeded in poly-lysine treated culture plates, and $24 \mathrm{~h}$ following nucleofection medium was changed according to experimental setup.

\subsection{Islets of Langerhans}

Human islets (average age of cadaveric donors $49.5 \pm 8.9$ years; range $40-58$ years; $n=4$ ) were provided through the Juvenile Diabetes Research Foundation (JDRF) Islet Distribution Program by Islet Cell Resource Centers in Geneva (Switzerland), Milan (Italy) and Lille (France). The use of human tissue for research was approved by the local ethical committee. Islets were cultured in
$5 \mathrm{mM}$ or $11 \mathrm{mM}$ glucose with $5 \%$ human serum in CMRL 1066 medium for $48 \mathrm{~h}$ before RNA extraction. Rodent islets were isolated as described previously $[21,22]$. $\mathrm{Db} / \mathrm{db}$ islets were harvested for RNA extraction immediately following isolation, and adult rat islets were cultured for $48 \mathrm{~h}$ in RPMI1640 with $5 \mathrm{mM}$ or $20 \mathrm{mM}$ glucose and $10 \%$ fetal bovine serum.

\subsection{RNA extraction and northern blotting}

RNA was extracted using TRI-Reagent (Sigma-Aldrich, Broendby, Denmark) according to the manufacturer's instructions, quantified using NanoDrop and stored at $-80^{\circ} \mathrm{C}$ until cDNA synthesis or northern blotting. Total RNA $(5 \mu \mathrm{g})$ was resolved in $15 \%$ TBE-Urea gels (Invitrogen, Novato, CA, USA), photographed and blotted to Hybond-XL membrane (GE Healthcare, Broendby, Denmark) by capillary transfer. RNA was cross-linked to membranes in UV Stratalinker (Stratagene/Agilent Technologies, Hoersholm, Denmark) at $120,000 \mu \mathrm{J} / \mathrm{cm}^{2}$ and baked for $60 \mathrm{~min}$ at $80^{\circ} \mathrm{C}$. Complementary LNA probe (Exiqon) for mature miR-29a was end-labeled with $\left[\gamma^{32} \mathrm{P}\right]$ dATP (Perkin Elmer, Waltham, MA, USA). Hybridization was performed using the ULTRAhyb-Oligo protocol (Ambion, Foster City, CA, USA). 


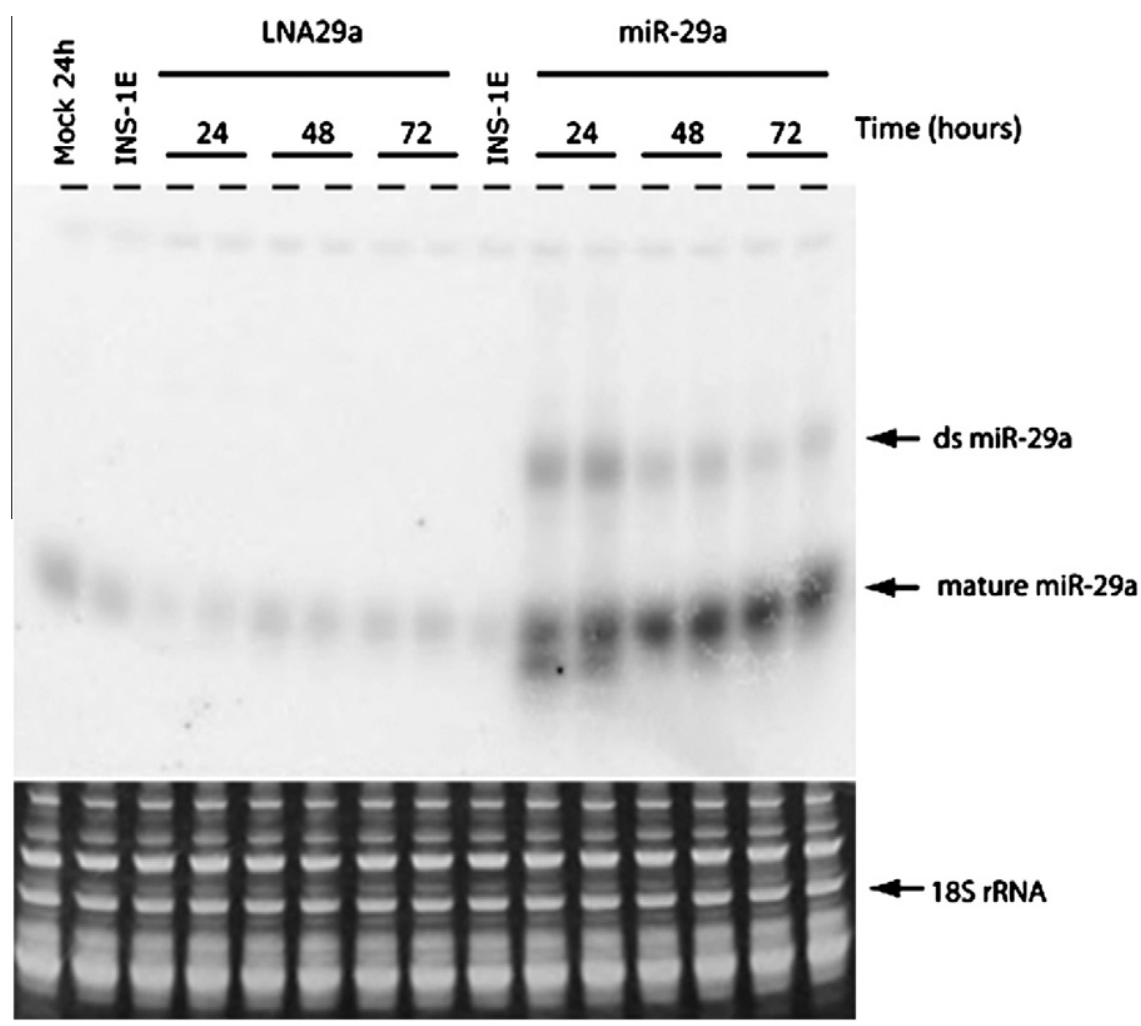

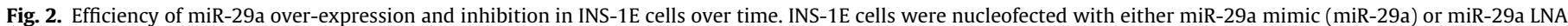

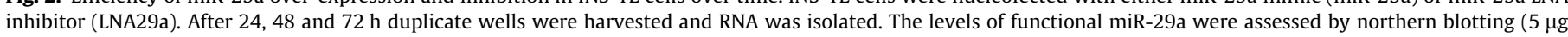

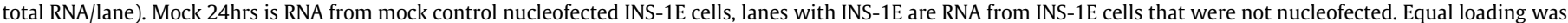
assessed by the intensity of the ${ }^{18} \mathrm{~S}$ rRNA band on the ethidium bromide dyed gel before blotting.

\subsection{Real-time $R T-Q-P C R$}

Gene-specific stem-looped RT-primers were used to prime cDNA synthesis of miR-29a as described previously [23]. Gene-specific cDNA syntheses were multiplexed with primer for the normalizing gene TFIIB. Q-PCR was performed using Quantitect SYBR reagent (Qiagen, Ballerup, Denmark) with melting curve detection using a MX3000P instrument (Agilent Technologies). TFIIB was used for normalization as its levels do not change when glucose levels are changed [24], whereas the levels of ${ }^{18} \mathrm{~S}$ and ${ }^{5} \mathrm{~S}$ rRNA levels were dependent on glucose treatments. Oligonucleotide sequences are available on request.

\subsection{Proliferation rate}

The xCELLigence System (Roche Diagnostics, Copenhagen, Denmark) was used to estimate INS-1E growth curves following nucleofection with miR-29a mimetic and negative control oligos. Measurements were performed according to the manufacturer's protocol. Briefly: poly-lysine treated E-plates were calibrated with $50 \mu \mathrm{l}$ complete growth medium before nucleofected cells were seeded in triplicate wells and growth followed for $48 \mathrm{~h}$. Experiments were performed in multiples of 4-8 of each treatment condition. Proliferation rates (Cell index) for wells were calculated from the slope of the linear part of the curve and the average level of $20 \mathrm{mM}$ glucose with Neg. ctrl. was set to $100 \%$ and data normalized to this. Data were normalized, because the Cell index changes between experiments. For statistical analysis data from all experiments were compared using one-way ANOVA followed by Tukey's multiple comparison tests.

\subsection{Determination of average cell size}

Nucleofected cells were seeded in 24-well plates and phase contrast images were obtained after 24 and $48 \mathrm{~h}$. Single cells were outlined in Image [25] and area determined. At least 30 cells per nucleofection were measured.

\subsection{GSIS assay}

Nucleofected cells were seeded in 24-wells in normal medium. The following day medium was changed to medium containing low $(5 \mathrm{mM})$ or high $(20 \mathrm{mM})$ glucose followed by culture for $48 \mathrm{~h}$. Three hours before the GSIS assay, medium was changed to RPMI 1640 containing $3 \mathrm{mM}$ glucose. Cells were subsequently stimulated for $2 \mathrm{~h}$ with $3 \mathrm{mM}$ or $20 \mathrm{mM}$ glucose in Krebs-Ringer buffer with $10 \mathrm{mM}$ HEPES, $5 \mathrm{mM} \mathrm{NaHCO}, 2.54 \mathrm{mM} \mathrm{CaCl}$ and $0.2 \%$ BSA. Insulin content in the buffer was determined with a rat insulin ELISA kit (Mercodia, Uppsala, Sweden). All glucose-treatments and stimulations were prepared in quadruplicate wells. Due to variance in cell numbers following nucleofection between individual experiments both relative (left side) and raw values (right side) are presented in Fig. 4. For relative values changes in GSIS are expressed as fold the value observed in control wells in order to facilitate comparison of data from several experiments.

\subsection{Statistics}

Students $t$-test was used to compare pairs of data. Multiple groups were analyzed using ANOVA with TUKEYs correction for multiple comparison. The significance level was 0.05 . Data are 
presented as a pool of replicate measurements from independent experiments.

\section{Results}

3.1. Regulation of miR-29a levels by glucose in human and rat islets of Langerhans and INS-1E cells

The expression levels of miR-29a in human islets of Langerhans and INS-1E cells treated with low $(5 \mathrm{mM})$ or high glucose $(11 \mathrm{mM}$ and $20 \mathrm{mM}$ respectively) for $48 \mathrm{~h}$ were assessed by real-time RT-QPCR or northern blotting. The expression levels of mature miR-29a in INS-1E cells (Fig. $1 \mathrm{~A}-\mathrm{C}$ ), rat and human pancreatic islets (Fig. 1D-E) increased $1.7 \pm 0.1(P<0.001), 1.5 \pm 0.3(P<0.05)$ and $1.23 \pm 0.06$-fold $(P<0.05)$, respectively, in response to increased glucose levels, and in INS-1E cells miR-29a up-regulation was dose-dependent (Fig. 1B-C). There was no effect of glucose on miR-29a primary transcript levels (Fig. 1B-C). Thus, both in the rat beta-cell line INS-1E and in rat and human islets of Langerhans mature miR-29a expression levels were increased by elevated glucose levels.

\subsection{Over-expression and inhibition of miR-29a in INS-1E cells}

Because the biological effects of high levels of glucose on INS-1E cells are normally observed after at least $48 \mathrm{~h}$ of glucose treatment, the efficiency of over-expressing and inhibiting miR-29a over time in INS-1E cells was assessed. Synthetic mature miR-29a (miR-29a) or miR-29a LNA inhibitor (LNA-29a, which binds and sequesters the endogenous miR-29a) was delivered to INS-1E cells by nucleofection and the levels of functional miR-29a were followed for up to $72 \mathrm{~h}$ after nucleofection and examined by northern blotting. As seen in Fig. 2 inhibition and over-expression of miR-29a was detectable for the $72 \mathrm{~h}$ of treatment, while inhibition decreased $48 \mathrm{~h}$ after nucleofection. Because the reduction by LNA-29a treatment appeared modest by northern blotting, the levels of miR-29a was also quantified by RT-Q-PCR. Mature miR-29a levels in LNA-29a treated cells was on average $42 \pm 17 \%$ of the level in Scr ctrl. treated cells $(n=4)$, which is similar to the level of inhibition observed previously with miR-21 in INS-1E cells [26]. The synthetic miR-29a is delivered as a modified dsRNA species, which is visible on the blot as a band above the mature miR-29a band (Fig. 2, 'ds miR-29a'). Thus, $48 \mathrm{~h}$ was chosen as the most appropriate time-point for assessment of the effects of miR-29a.

\subsection{Proliferation and size of clonal INS-1E beta-cells over-expressing miR-29a}

MiR-29a has been reported to be associated with cancer and/or increased proliferation in various cell types. MiR-29a over-expression increased proliferation in INS-1E beta-cells by $41.9 \pm 8.0 \%$ $(P<0.01)$ in $3 \mathrm{mM}$ glucose medium and by $55.9 \pm 13.9 \%$ $(P<0.001)$ in $20 \mathrm{mM}$ glucose medium compared with cells transfected with the negative control miR (Fig. 3A). The area of cells was unchanged by over-expression or depletion of miR-29a (Fig. 3B).

The level of miR-29a was assessed in islets from $\mathrm{db} / \mathrm{db}$ mice and controls at the age of $8-15$ weeks, at which time the mice have developed diabetes (Fig. 3C). The relative level of miR-29a was appeared lower in $\mathrm{db} / \mathrm{db} \mathrm{vs}$. db/+ islets at 15 weeks of age, however, this did not reach statistical significance $(\mathrm{db} / \mathrm{db}: 1.1 \pm 0.5 \mathrm{vs}$. $\mathrm{db} /+$ : $4.1 \pm 1.9, P=0.13, N=5-6$ islet preparations). Thus, although speculative diabetic $\mathrm{db} / \mathrm{db}$ mouse islets may have decreased miR-29a levels, which corresponds well with the very decreased
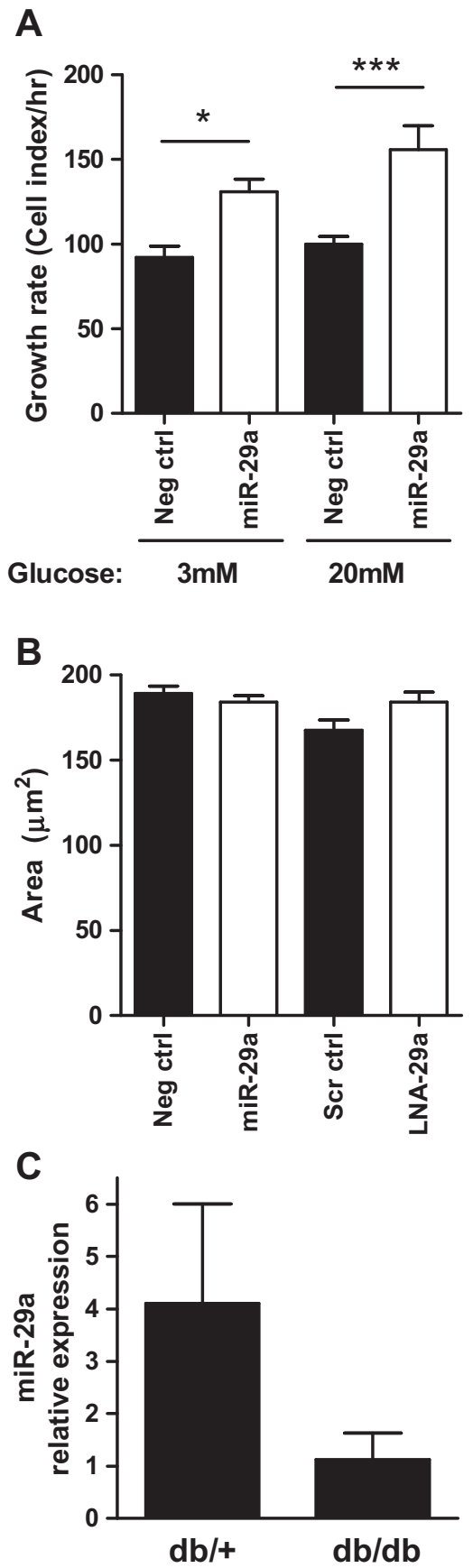

Fig. 3. Effects of miR-29a on proliferation and cell size of INS-1E beta-cells. (A) Proliferation rate (cell index) of nucleofected INS-1E cells assessed at $3 \mathrm{mM}$ glucose medium and $20 \mathrm{mM}$ glucose medium. (B) Cell area of nucleofected INS-1E cells was determined as described in research design and methods. Mean \pm SEM from 3 independent experiments, ${ }^{*} P<0.05,{ }^{* * *} P<0.001$ as indicated by bars. (C) MiR-29a levels were assessed by RT-Q-PCR in isolated islets from $\mathrm{db} / \mathrm{db}$ or $\mathrm{db} /+$ mice aged 15 weeks.

proliferation of $\beta$-cells in this model, when diabetes has developed [27]. However, further studies are needed to confirm this.

3.4. Effects of miR-29a over-expression and depletion on glucosestimulated insulin secretion

To test if the glucose-induced up-regulation of miR-29a affected insulin secretion, INS-1E beta-cells were transfected with miR-29a mimic for over-expression or with LNA-modified antisense 
A

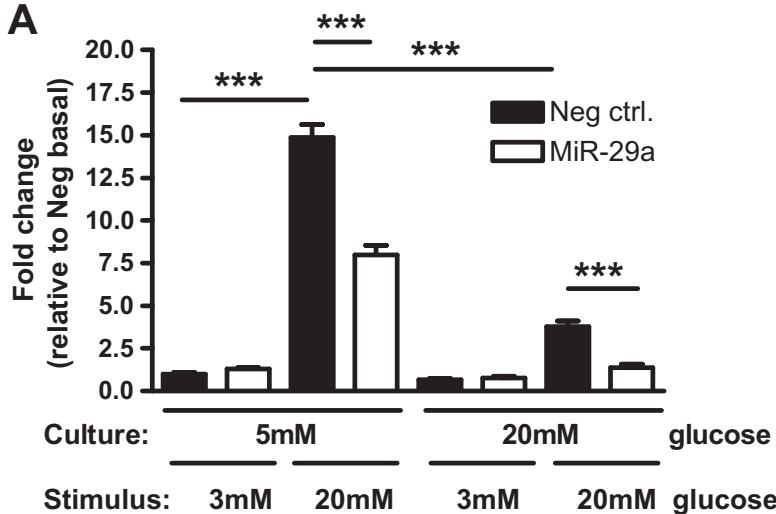

B

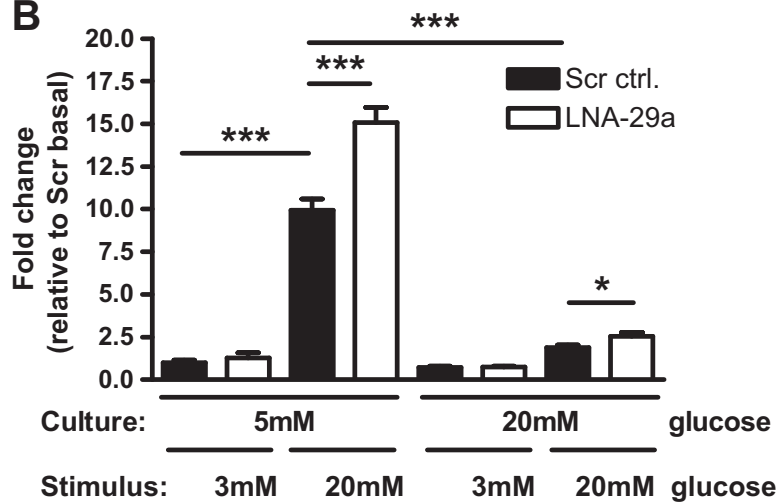

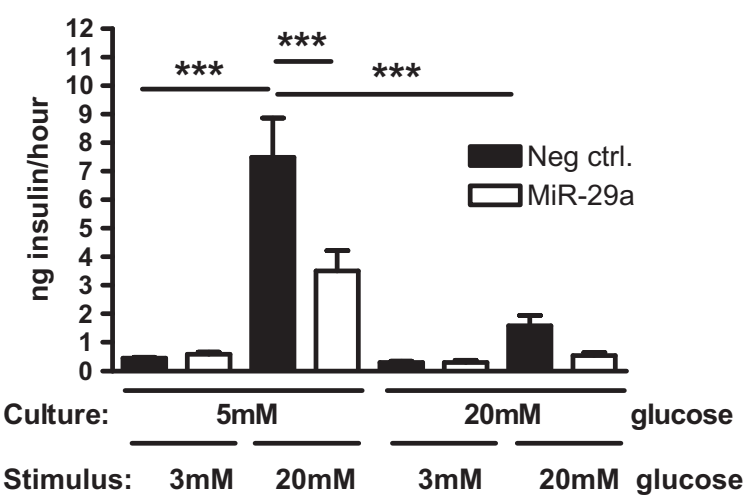

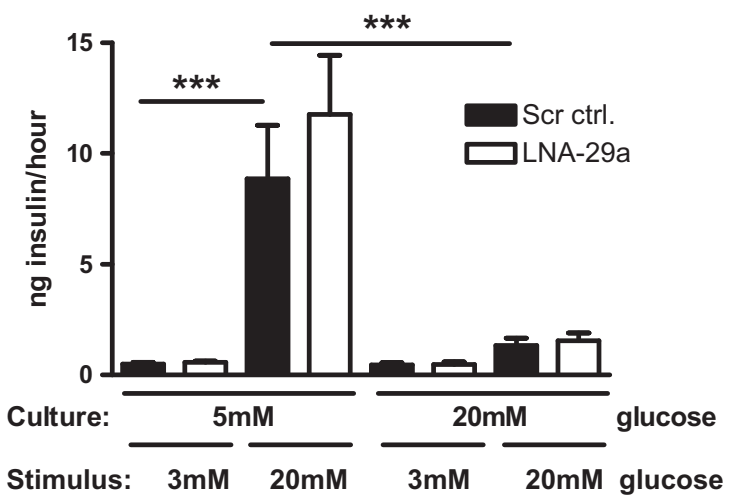

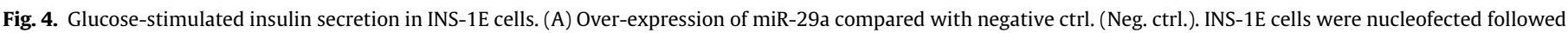

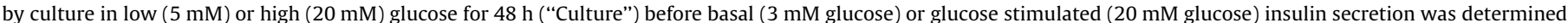

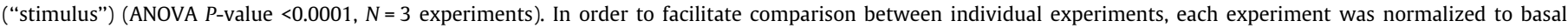

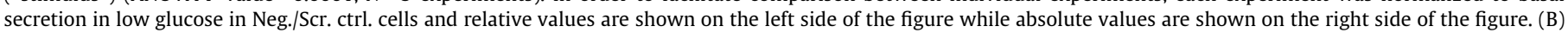

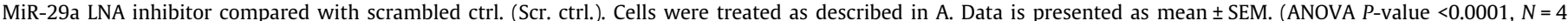
experiments) $\left({ }^{*} P<0.05,{ }^{* * *} P<0.001\right)$.

miR-29a for depletion of endogenous miR-29a. Cells were cultured in either $5 \mathrm{mM}$ (low) or in $20 \mathrm{mM}$ glucose (high) medium to induce glucose toxicity. INS-1E beta-cells cultured in $5 \mathrm{mM}$ glucose elicit a robust insulin secretion response from $1.0 \pm 0.2$ to $14.9 \pm 0.8$-fold $(P<0.001)$ (Fig. 4A left side, Culture: $5 \mathrm{mM}$, miRNA mimic Neg. ctrl. transfection) or from $1.0 \pm 0.2$ to $9.9 \pm 0.7$-fold $(P<0.001)$ (Fig. 4B left side, Culture: $5 \mathrm{mM}$, LNA Scr. ctrl. transfection) when stimulated with $20 \mathrm{mM}$ glucose compared with basal insulin secretion at $3 \mathrm{mM}$ glucose. Absolute values for GSIS are displayed in the right side panels of Fig. 4.

Over-expression of miR-29a significantly decreased insulin secretion at $20 \mathrm{mM}$ glucose (Fig. $4 \mathrm{~A}$ left side, Culture: $5 \mathrm{mM}$, miR-29a: $8.0 \pm 0.6$-fold vs. Neg. ctrl.: $14.9 \pm 0.8$-fold of basal insulin secretion $(P<0.001))$. The decrease in GSIS by miR-29a over-expression is similar to but not quite as large as the effect of chronically increased glucose concentration on insulin secretion in INS-1E beta-cells ((Fig. 4A left side, Culture: $5 \mathrm{mM}$ Neg. ctrl.: $14.9 \pm 0.8$ vs. Culture: $20 \mathrm{mM}$ Neg. ctrl.: $3.8 \pm 0.3(P<0.001))$ [28]. Moreover, over-expression of miR-29a further decreased GSIS (Fig. 4A left side, Culture: $20 \mathrm{mM}$, miR-29a: $1.4 \pm 0.2$-fold vs. Neg. ctrl.: $3.4 \pm 0.3$-fold of basal secretion $(P<0.001)$ ).

Depletion of endogenous miR-29a in INS-1E cells cultured in $5 \mathrm{mM}$ glucose markedly increased GSIS compared with Scr. ctrl. (Fig. 4B left side, Culture $5 \mathrm{mM}$, Scr. ctrl.: $9.9 \pm 0.7$-fold vs. LNA29a: $15.1 \pm 0.9$-fold of basal insulin secretion, $(P<0.001))$. There was a tendency that transfections of INS-1E cells with LNA-oligos decreased maximal GSIS, but compared with earlier observations from our laboratory, this change was not significant [20]. Furthermore, inhibition of miR-29a in cells cultured with $20 \mathrm{mM}$ glucose also increased GSIS slightly (Fig. 4B left side, Culture: $20 \mathrm{mM}$, LNA-Scr. ctrl.: $1.9 \pm 0.1$-fold vs. LNA-29a: $2.5 \pm 0.2$-fold of basal Scr. ctrl. upon $20 \mathrm{mM}$ glucose stimulation $(P<0.05)$ ), but due to variations between experiments, this was not significant when data are presented with absolute values (Fig. 4B, right side). Thus, miR-29a up-regulation impairs GSIS while its inhibition improves insulin secretion. The insulin content of cells was not determined, and it cannot be excluded that miR-29a also has an impact on insulin content. However, in the mouse beta-cell line MIN6, insulin content is not affected by miR-29a over-expression [29]. It is possible that mir-29a affects glucose uptake into beta-cells and in this way influences insulin secretion, but there are no predicted miR-29a targets which should influence glucose uptake or glycolysis, and the mRNA for the rate-limiting enzyme for glycolytic flux, glucokinase, does not change in response to miR-29a over-expression (Fig. 1S). However, in order to investigate this issue further, glucose transport and rate of glycolysis should be determined.

\section{Discussion}

Prolonged exposure of beta-cells to high levels of glucose decreases GSIS $[2,30]$. The current results show that over-expression of miR-29a, up-regulated by glucose in human islets of Langerhans and in INS-1E beta-cells, decreased GSIS markedly in INS-1E cells that normally exhibit a robust insulin secretion 
response. Inhibition of miR-29a increases GSIS, suggesting that endogenous miR-29a exert a tonic inhibition on GSIS. Even though inhibition of miR-29a increased GSIS in cells cultured in $20 \mathrm{mM}$ glucose, inhibition of endogenous miR-29a function did not compensate for the negative effects of high glucose on insulin secretion, which may be due to incomplete knock-down at increased glucose concentrations, where endogenous miR-29a levels are increased. However, it is likely that activation of other glucotoxic pathways such as UCP2 induction also takes place [31].

Increased glucose levels is a powerful mitogen for beta-cells [5]. Concordant with this miR-29a increased INS-1E cell growth. Therefore, one effect of glucose-induced up-regulation of miR-29a may be to promote proliferation as the demand for more beta-cells increases upon prolonged exposure to elevated levels of glucose. MiR-29a is preferentially expressed in $\beta$-cells in islets [26,32], and the possible lower level of miR-29a in $\mathrm{db} / \mathrm{db}$ islets may also in part be due to a decreased number of beta-cells per islet in $\mathrm{db} / \mathrm{db}$ diabetic islets.

It was recently shown that a certain normal level of miR-29a expression is critical for maintaining a low expression of monocarboxylate transporter 1 (Mct1) in beta-cells denying entrance of lactate into beta-cells [32]. Our data suggest that an increased amount of miR-29a is unfavorable for insulin secretion while it promotes beta-cell proliferation.

MiR-29 family members also promote apoptosis of mouse betacells [29]. Although there may be a species or cell-line difference, it is highly likely that the increased proliferation happens in context with increased cell death, which is a phenomenon of cancer cells [33].

Our results demonstrate that glucose-induced miR-29a impairs beta-cell function by decreasing GSIS. He et al. [17] showed that miR-29a up-regulation in adipocytes caused insulin resistance. As miR-29a has been shown to be up-regulated by glucose in several tissues [18] and increased in serum of type 2 diabetic patients [34] it is possible that miR-29a up-regulation promotes development of type 2 diabetes by at least two mechanisms: via decreased insulin secretion in beta-cells and via peripheral insulin resistance. This suggests that therapy with miR-29a LNA inhibitor could be beneficial for type 2 diabetic patients in order to improve both beta-cell function as well as glucose uptake in peripheral tissues. As shown recently, miR-29 family members may also be involved in cytokine-mediated beta-cell dysfunction [29].

The molecular mechanisms causing the alterations in normal function of beta-cells upon prolonged exposure to increased levels of glucose are still incompletely understood. Here, we show that forced expression of the glucose-up-regulated miR-29a mimics the effect of high glucose levels on beta-cells. Further, inhibition of miR-29a improves beta-cell function, even when beta-cell function is impaired by prolonged culture at increased glucose levels. At the same time, miR-29a over-expression increases beta-cell proliferation. Therefore, the up-regulation of miR-29a by glucose could be a link between glucose-induced proliferation and betacell dysfunction. These findings suggest that glucose-induced upregulation of miR-29a may constitute a mechanism for beta-cell dysfunction and may contribute to the progression from impaired glucose tolerance to overt type 2 diabetes.

\section{Acknowledgments}

We are very grateful for the skilled technical assistance of Kirsten Olesen, Roskilde University and Vibeke Nielsen, Novo Nordisk A/S. LTD, ML and JHN has been and TRC is employed by and own stocks in Novo Nordisk A/S, a pharmaceutical company selling diabetes products. These studies were supported by the Danish Research Council for Technology and Production and the Danish microRNA Consortium.

\section{Appendix A. Supplementary data}

Supplementary data associated with this article can be found, in the online version, at http://dx.doi.org/10.1016/j.bbrc.2012.08.082.

\section{References}

[1] K.J. Chang-Chen, R. Mullur, E. Bernal-Mizrachi, Beta-cell failure as a complication of diabetes, Rev. Endocr. Metab. Disord. 9 (2008) 329-343.

[2] B.B. Lowell, G.I. Shulman, Mitochondrial dysfunction and type 2 diabetes, Science 307 (2005) 384-387.

[3] M. Anello, R. Lupi, D. Spampinato, S. Piro, M. Masini, U. Boggi, P.S. Del, A.M Rabuazzo, F. Purrello, P. Marchetti, Functional and morphological alterations of mitochondria in pancreatic beta cells from type 2 diabetic patients, Diabetolog 48 (2005) 282-289.

[4] P. Maechler, N. Li, M. Casimir, L. Vetterli, F. Frigerio, T. Brun, Role of mitochondria in beta-cell function and dysfunction, Adv. Exp. Med. Biol. 654 (2010) 193-216.

[5] L.C. Alonso, T. Yokoe, P. Zhang, D.K. Scott, S.K. Kim, C.P. O'Donnell, A. GarciaOcana, Glucose infusion in mice: a new model to induce beta-cell replication, Diabetes 56 (2007) 1792-1801.

[6] D.P. Bartel, C.Z. Chen, Micromanagers of gene expression: the potentially widespread influence of metazoan microRNAs, Nat. Rev. Genet. 5 (2004) 396400.

[7] T.M. Rana, Illuminating the silence: understanding the structure and function of small RNAs, Nat. Rev. Mol. Cell Biol. 8 (2007) 23-36.

[8] L. Song, R.S. Tuan, MicroRNAs and cell differentiation in mammalian development birth defects, Res. C. Embryo. Today 78 (2006) 140-149.

[9] V. Plaisance, A. Abderrahmani, V. Perret-Menoud, P. Jacquemin, F. Lemaigre, R. Regazzi, MicroRNA-9 controls the expression of Granuphilin/Slp4 and the secretory response of insulin-producing cells, J. Biol. Chem. 281 (2006) 2693226942.

[10] N. Baroukh, M.A. Ravier, M.K. Loder, E.V. Hill, A. Bounacer, R. Scharfmann, G.A. Rutter, E. Van Obberghen, MicroRNA-124a regulates Foxa2 expression and intracellular signaling in pancreatic beta-cell lines, J. Biol. Chem. 282 (2007) 19575-19588.

[11] P. Lovis, S. Gattesco, R. Regazzi, Regulation of the expression of components of the exocytotic machinery of insulin-secreting cells by microRNAs, Biol. Chem. 389 (2008) 305-312.

[12] M.N. Poy, L. Eliasson, J. Krutzfeldt, S. Kuwajima, X.S. Ma, P.E. MacDonald, S. Pfeffer, T. Tuschl, N. Rajewsky, P. Rorsman, M. Stoffel, A pancreatic isletspecific microRNA regulates insulin secretion, Nature 432 (2004) 226-230.

[13] M.N. Poy, J. Hausser, M. Trajkovski, M. Braun, S. Collins, P. Rorsman, M. Zavolan, M. Stoffel, miR-375 maintains normal pancreatic a- and b-cell mass, Proc. Natl. Acad. Sci. USA (2009).

[14] R.G. Fred, C.H. Bang-Berthelsen, T. Mandrup-Poulsen, L.G. Grunnet, N. Welsh, High glucose suppresses human islet insulin biosynthesis by inducing miR133a leading to decreased polypyrimidine tract binding protein-expression, PLoS One 5 (2010) e10843.

[15] X. Tang, L. Muniappan, G. Tang, S. Ozcan, Identification of glucose-regulated miRNAs from pancreatic beta\} cells reveals a role for miR-30d in insulin transcription, RNA 15 (2009) 287-293.

[16] P. Lovis, E. Roggli, D.R. Laybutt, S. Gattesco, J.Y. Yang, C. Widmann, A. Abderrahmani, R. Regazzi, Alterations in microRNA expression contribute to fatty acid-induced pancreatic beta-cell dysfunction, Diabetes 57 (2008) 27282736 .

[17] A. He, L. Zhu, N. Gupta, Y. Chang, F. Fang, Over-expression of miR-29, highly upregulated in diabetic rats, leads to insulin resistance in 3T3-L1 adipocytes, Mol. Endocrinol. (2007).

[18] B.M. Herrera, H.E. Lockstone, J.M. Taylor, Q.F. Wills, P.J. Kaisaki, A. Barrett, C. Camps, C. Fernandez, J. Ragoussis, D. Gauguier, M.I. McCarthy, C.M. Lindgren, MicroRNA-125a is over-expressed in insulin target tissues in a spontaneous rat model of Type 2 diabetes, BMC Med. Genomics 2 (2009) 54.

[19] A.K. Pandey, G. Verma, S. Vig, S. Srivastava, A.K. Srivastava, M. Datta, miR-29a levels are elevated in the $\mathrm{db} / \mathrm{db}$ mice liver and its overexpression leads to attenuation of insulin action on PEPCK gene expression in HepG2 cells, Mol. Cell Endocrinol. 332 (2011) 125-133.

[20] L.T. Dalgaard, P. Thams, L.W. Gaarn, J. Jensen, Y.C. Lee, J.H. Nielsen, Suppression of FAT/CD36 mRNA by human growth hormone in pancreatic beta-cells, Biochem. Biophys. Res. Commun. 410 (2011) 345-350.

[21] J. Jensen, E.D. Galsgaard, A.E. Karlsen, Y.C. Lee, J.H. Nielsen, STAT5 activation by human GH protects insulin-producing cells against interleukin-1beta, interferon-gamma and tumour necrosis factor-alpha-induced apoptosis independent of nitric oxide production, J. Endocrinol. 187 (2005) 25-36.

[22] L.T. Dalgaard, A. Roeske-Nielsen, J.E. Månsson, K. Buschard, Sulfatide glycolipid protects insulin-producing cells against cytokine-induced apoptosis, a possible role in diabetes, Diabetes Metab. Res. Rev. 26 (2010) 631-638.

[23] X. Chen, Y. Ba, L. Ma, X. Cai, Y. Yin, K. Wang, J. Guo, Y. Zhang, J. Chen, X. Guo, Q. Li, X. Li, W. Wang, Y. Zhang, J. Wang, X. Jiang, Y. Xiang, C. Xu, P. Zheng, J. Zhang, R. Li, H. Zhang, X. Shang, T. Gong, G. Ning, J. Wang, K. Zen, J. Zhang, C.Y. Zhang, Characterization of microRNAs in serum: a novel class of biomarkers for diagnosis of cancer and other diseases, Cell Res. 18 (2008) 997-1006. 
[24] K. Ravnskjaer, M. Boergesen, L.T. Dalgaard, S. Mandrup, Glucose-induced repression of PPARalpha gene expression in pancreatic beta-cells involves PP2A activation and AMPK inactivation, J. Mol. Endocrinol. 36 (2006) 289-299.

[25] M.D. Abramoff, P.J. Magalhaes, S.J. Ram, Image processing with image, J. Biophoton. Int. 11 (2004) 36-42.

[26] L. Larsen, M.W. Rosenstierne, L.W. Gaarn, A. Bagge, L. Pedersen, C.M. Dahmcke, J.H. Nielsen, L.T. Dalgaard, Expression and localization of microRNAs in perinatal rat pancreas role of miR-21 in regulation of cholestero metabolism, PLoS One 6 (2011) e25997.

[27] W.L. Chick, A.A. Like, Studies in the diabetic mutant mouse. 3. Physiological factors associated with alterations in beta cell proliferation, Diabetolog 6 (1970) 243-251.

[28] A. Boucher, D. Lu, S.C. Burgess, S. Telemaque-Potts, M.V. Jensen, H. Mulder, M.Y. Wang, R.H. Unger, A.D. Sherry, C.B. Newgard, Biochemical mechanism of lipid-induced impairment of glucose-stimulated insulin secretion and reversal with a malate analogue, J. Biol. Chem. 279 (2004) 27263-27271.
[29] E. Roggli, S. Gattesco, D. Caille, C. Briet, C. Boitard, P. Meda, R. Regazzi, Changes in MicroRNA expression contribute to pancreatic beta-cell dysfunction in prediabetic NOD mice, Diabetes 2012.

[30] V. Poitout, R.P. Robertson, Glucolipotoxicity fuel excess and beta-cell dysfunction, Endocr. Rev. 29 (2008) 351-366.

[31] S. Krauss, C.Y. Zhang, L. Scorrano, L.T. Dalgaard, J. St-Pierre, S.T. Grey, B.B. Lowell, Superoxide-mediated activation of uncoupling protein 2 causes pancreatic b-cell dysfunction, J. Clin. Invest. 112 (2003) 1831-1842.

[32] T.J. Pullen, G. da Silva Xavier, G. Kelsey, G.A. Rutter, miR-29a and miR-29b contribute to pancreatic beta-cell-specific silencing of monocarboxylate transporter 1 (Mct1), Mol. Cell Biol. 31 (2011) 3182-3194.

[33] R. Scatena, Mitochondria cancer: a growing role in apoptosis cancer cell metabolism and dedifferentiation, Adv. Exp. Med. Biol. 942 (2012) 287-308.

[34] L. Kong, J. Zhu, W. Han, X. Jiang, M. Xu, Y. Zhao, Q. Dong, Z. Pang, Q. Guan, L. Gao, J. Zhao, L. Zhao, Significance of serum microRNAs in pre-diabetes and newly diagnosed type 2 diabetes: a clinical study, Acta Diabetol. (2010). 